\title{
The Relationship between Religious Orientation, Moral Integrity, Personality, Organizational Climate and Anti Corruption Intentions in Indonesia
}

\author{
Zulfa Indira Wahyuni, Yufi Adriani, and Zahrotun Nihayah
}

\begin{abstract}
Indonesia is a religion and strongly implemented their religion belief value on their everyday life. However, the issue of corruption in Indonesia is increasingly happening and should receive special attention. It shows that the corruptions behavior did not implement what being teach in their religion. Furthermore, the data show that corruption also involves the people who are in government institution. The objective of this study is to see how the religious orientation, personality, moral integrity, organizational climate can affect the intentions of the anti - corruptions behavior. The study involved 203 Civil Servants in the Ministry of Religion Affairs in Indonesia as a representative population from government institutions. They were administered a set of scales. Each scale is made on a 4-point Likert rating scale (range from strongly agree to strongly disagree). By using SPSS software and LISRELL, multiple regression analysis was used to analyze the research hypotheses. The result of this research shows that all independent variables did bring impact to dependent variable.
\end{abstract}

Index Terms - The anti corruption intentions, moral integrity, organizational climate, personality, religious orientation.

\section{INTRODUCTION}

One of the biggest problem in Indonesia is the corruption's problem. The current data indicates that Indonesia get ranked 114 in the world's most corrupt countries (www.tempo.co, 2013) [1]. Even though, the state already has the commission called KPK (Corruption Eradication Comission), an agency whose primary mission is the prevention and eradication of corruption, yet, there was still much corruption in Indonesia. Furthermore, KPK indicates if the Ministry of Religious Affairs be the most corrupt institution in Indonesia (http://pendidikanagama.com, 2011) [2]. In fact, this ministry should be a major part to educate society to become a person who upholds the integrity so people will have no intentions to do the corruption behavior.

Intention is one's intention to perform a set or pattern behavior (Ancok, 1992) [3]. In this case a person who has the intention to avoid corruption, which can direct it not to corrupt behavior. Many factors that we believed will influence the anti-corruption's intentions. One of them is a religious orientation that showed individual's perspective on the position of religion in his life, which determines the pattern of the individual relationship with religion. Further to this, Allport and Ross (1967) [4] distinguish the religious orientation of the two typologies, named intrinsic and

Manuscript received June 2, 2014; revised August 4, 2014.

The authors are with the Faculty of Psychology, State Islamic University of Jakarta, Indonesia (e-mail: zulfara@yahoo.com). extrinsic. People who has embraced an intrinsic religious orientation as the purpose of life, has a strong religious motive and trying to internalize religious values into his life. While someone who has extrinsic religious orientation using religion only as a way to reach their goals but do not try to internalize it into their own heart. Thus, people who have an intrinsic religious orientation will be running behavior in line with beliefs that have been internalized, including avoiding behaviors that are considered contrary to the religion values such as corruption behavior. The meaning of corruption itself was when people using authority and positions for personal benefit and harm the public interest. The other factors that also influence a person to do corruption or not is the personality. Personality is everything that allows a prediction of what a person will do in a given situation. In this study, we focused on personality Hexaco Personality Type, which consists of six dimensions, Honesty-Humility (H), Emotionality (E), Extraversion (X), Agreeableness (A), Conscientiousness (C), and Openness to Experience (O) (Ashton, Lee, et al., 2004) [5]. Indeed, a person whose personality is dominated by Honesty-Humility where includes simplicity, honesty, and avoiding greed will have a high intention to do corruption behavior.

Furthermore, other factors that also make contribution to the intention of anti-corruption is the existence of moral integrity, because the lack of moral strength will lead some people to do corruption (Ministry of Religious Affairs, 2004) [6]. Moral integrity can be defined as the consistency of actions, values, methods, principles, expectations and outcomes in ethics (ethic-intelligence.com, 2012) [7].

In addition to internal factors such as those mentioned above, other factors that influence the intention corruption are external factors, such as organizational climate. Organizational climate is a concept that describes the atmosphere of the organization's internal environment and was perceived by its members during the move in order to achieve organizational goals (Davis and Newstorm, in Wirawan 2011) [8]. Bologna (in the Department of Religious Affairs, 2004) states that main cause of the corruption's behavior is the opportunity to do it especially when being associated with a system that did not have a strict monitoring system so that will allows people to manipulate or to do fraud.

Based on the above explanation, we want to know further whether the religious orientation, personality, moral integrity and organizational climate variable have direct influence to the anti-corruption's intentions. 


\section{BODY PART}

\section{A. Theoretical Background}

In this research, we tried to define each variable with scientific definitions. Fishbein and Ajzen (1975) [9] suggested that the intention is cognitive representation of a person's readiness to implement a particular behavior and is seen as the closest antecedent to behavior. In addition, Ancok (1992) stated that the intention can be defined as a person's intention to perform a behavior. Intention plays an important role in directing the action, which connects deliberation that believed and desired by someone with a specific action. Anti-corruption intention is the intention of the individual to avoid corruption. According to the legal dictionary, corruption means damaged, like accepting bribes, embezzled money / goods belonging to the company or the state, receiving money by using public office for personal gain, misappropriation or embezzlement of state funds or the company as a person working for personal interests or others.

Types of corruption:

1) Slippery, a corruption that is deliberately giving bribes to obtain favorable decisions to the briber and the bribed person

2) Exortion system, use their authority for personal gain, take refuge in the legitimacy and power

3) Provocation system, better known as crime corruption conspiracy or collusion, which provides opportunities for partners to explore opportunities relating to the protection of the law, regulations and the power that can bring personal gain or groups

Religious orientation is an individual perspective on the position of religion in his life, which determine the pattern of individual relationship with religion. This viewpoint will affect the behavior of individuals in the interpretation of religious teachings and do what he regards as religious orders Allport and Ross (1967) divides religious orientation into two typologies, extrinsic and intrinsic. Extrinsically religious oriented individuals tend to use religion in the framework of usability. Religion is useful to support the self-confidence, improve the status, defend against the reality or give sanction to a way of life. They are driven by what they can get out of religion, belief and more oriented to the internal life without fixing the external consequences. While the intrinsically religious oriented shows main motivation in religion, religion is more focused on the interests that organize and mobilize the entire life activity. They were trying to internalize and follow on what has been teaching by their religion. They will integrate and synchronize the belief and religious teachings.

Personality is the dynamic organization of psychophysical systems that determine individual characteristics and behaviors thought. Hexaco personality structure is a personality type that consists of a six-dimensional model developed by Ashton and Lee of some lexical studies (Ashton, Lee, et al. 2004). Six factors or dimensions, including the Honesty-Humility $(\mathrm{H})$, Emotionality (E), Extraversion (X), Agreeableness (A), Conscientiousness (C), and openness to Experience $(\mathrm{O})$.

Hexaco Aspects:

1) Honesty - Humility : Sincerity, Fairness, Greed Avoidance, Modesty
2) Emotionality : Fearfulness, Anxiety, Dependence, Sentimentality

3) Extraversion : Social Self-Esteem, Social Boldness, Sociability, Liveliness

4) Agreeableness : Forgivingness, Gentleness, Flexibility, Patience

5) Conscientiousness : Organization, Diligence, Perfectionisme, Prudence

6) Openness to Experience : Aesthetic Appreciation, Inquistiveness, Creativity, Unconventionality

Integrity and honesty is regarded as the truth or accuracy of one's actions. Moral integrity is a concept of consistency of actions, values, methods, principles, expectations and outcomes in ethics (ethic-intelligence.com, 2012). Moral integrity consists of three components;

1) Moral discernment, the ability to distinguish between morally right and wrong. This has to do with good and bad according to him and others.

2) Consistent behavior, ability to act on what he believed, means the person who has the moral integrity to act reliable or consistent at all times and circumstances, even at difficult time.

3) Public justification, people who have the moral integrity will publicly disclose that he is acting in accordance with the beliefs that are the result of reflection and moral evaluation. People with moral integrity is open and honest stating what he believed to the public

Organizational climate is an organization's internal environment relatively ongoing, experienced by members of an organization, influencing their behavior and can be described in terms of a set of characteristics or nature of the organization (Tagiuri and Litwit In Wirawan, 2008). While Mezias \& Starbuck (in Riyanti \& Dahesihsari, 2008) states that organizational climate is a series of working environment can be measured by the collective perception of the organization's members who live and work in the environment of an organization. Dimensions of organizational climate is conformity, responsibility, standards, rewards, organizational clarity, warmth, and support and leadership.

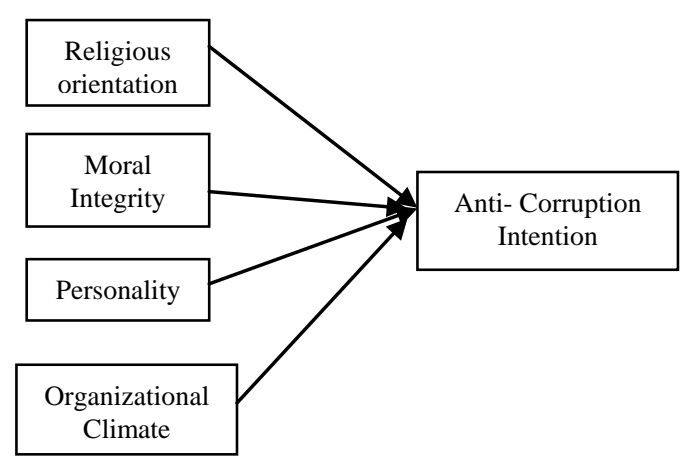

Fig. 1. Conceptual framework

\section{B. Research Methodology}

The population in this study was a civil servant in the Ministry of Religious Affairs. For this research we took 203 employees from various department in Ministry of Religious Affairs. The data collection techniques using questionnaire with Likert scale and consists of five subscales that assessed all variables. 
Sample selection method is simple random sampling. Processing data using path analysis model and Lisrell for data processing.

Here are the scales that we use to collect data.

TABLE I: RELIGIOUS ORIENTATION SCALE

\begin{tabular}{|c|c|}
\hline Dimensions & Items \\
\hline \multirow[t]{7}{*}{ Extrinsic } & $\begin{array}{l}\text { Although I believe in my religion, I feel there } \\
\text { are many other more important things in my } \\
\text { life }\end{array}$ \\
\hline & $\begin{array}{l}\text { It doesn't matter so much what I believe so } \\
\text { long as I lead a moral life }\end{array}$ \\
\hline & $\begin{array}{l}\text { The primary purpose of prayer is to gain relief } \\
\text { and protection }\end{array}$ \\
\hline & $\begin{array}{l}\text { The church/mosque is most important as a } \\
\text { place to formulate good social relationship }\end{array}$ \\
\hline & $\begin{array}{l}\text { What religion offers me most is comfort when } \\
\text { sorrows and misfortune strike }\end{array}$ \\
\hline & $\begin{array}{l}\text { I pray chiefly because I have been taught to } \\
\text { pray }\end{array}$ \\
\hline & $\begin{array}{l}\text { Although I am a religious person I refuse to let } \\
\text { religious considerations influence my everyday } \\
\text { affairs }\end{array}$ \\
\hline \multirow[t]{8}{*}{ Intrinsic } & $\begin{array}{l}\text { It is important for me to spend periods of time } \\
\text { in private religious thought and meditation }\end{array}$ \\
\hline & $\begin{array}{l}\text { If not prevented by anavoidable circumstances, } \\
\text { I attend church/mosque }\end{array}$ \\
\hline & $\begin{array}{l}\text { I try hard to carry my religion over into all my } \\
\text { other dealings in life }\end{array}$ \\
\hline & $\begin{array}{l}\text { The prayers I say when I am alone carry as } \\
\text { much meaning and personal emotion as those } \\
\text { said by me during services }\end{array}$ \\
\hline & $\begin{array}{l}\text { Quite often I have been keenly aware of the } \\
\text { presence of God }\end{array}$ \\
\hline & I read literature about my faith \\
\hline & $\begin{array}{l}\text { My religious beliefs are really what lie behind } \\
\text { my whole approach to life }\end{array}$ \\
\hline & $\begin{array}{l}\text { Religion is especially important because it } \\
\text { answers many questions about the meaning of } \\
\text { life }\end{array}$ \\
\hline
\end{tabular}

TABLE II: ORGANIZATIONAL CLIMATE SCALE

\begin{tabular}{|c|c|}
\hline Dimensions & Items \\
\hline $\begin{array}{l}\text { Structure } \\
\text {-Employees feel their work is well } \\
\text { defined } \\
\text {-There is clarity about who is doing a } \\
\text { task } \\
\text {-There is clarity about who has the } \\
\text { authority to make decisions }\end{array}$ & $\begin{array}{l}\text { 1.I know clearly my duty in this } \\
\text { office } \\
\text { 2.My boss explains well what should } \\
\text { I do in this division } \\
\text { 3.Every employee knows clearly } \\
\text { their duty in this office }\end{array}$ \\
\hline $\begin{array}{l}\text { Standards } \\
\text {-Employees are always working to } \\
\text { find ways to improve performance } \\
\text {-Employees have higher } \\
\text { expectations for their performance }\end{array}$ & $\begin{array}{l}\text { 1.I feel motivated to work better } \\
\text { from day to day } \\
\text { 2.I always put my best effort in my } \\
\text { work }\end{array}$ \\
\hline $\begin{array}{l}\text { Responsibility } \\
\text {-Employees feel encouraged to solve } \\
\text { their own problems } \\
\text {-Employees do jobs that meet the } \\
\text { quality standards of work even } \\
\text { facing a risk } \\
\text {-Employees do the job with a new } \\
\text { approach }\end{array}$ & $\begin{array}{l}\text { 1.If I can not do the task, I will leave } \\
\text { it } \\
\text { 2.I got the trust to fully responsible } \\
\text { for my work } \\
\text { 3.I keep working my job even facing } \\
\text { a risk }\end{array}$ \\
\hline $\begin{array}{l}\text { Awards } \\
\text {-Company gives rewards and } \\
\text { punishments fairly } \\
\text {-Completion of a good job } \\
\text { consistently rewarded }\end{array}$ & $\begin{array}{l}\text { 1.I get the reward according to my } \\
\text { performance } \\
\text { 2.If I make a mistake, I do not get a } \\
\text { punishment } \\
\text { 3.My boss never give me appropriate } \\
\text { compliment for my achievement }\end{array}$ \\
\hline $\begin{array}{l}\text { Support } \\
\text {-Employees feel that they are part of } \\
\text { a well-functioning teams } \\
\text {-Employees getting help from } \\
\text { superiors if experiencing difficulty in } \\
\text { performing tasks } \\
\text {-Employees feel togetherness, do not } \\
\text { feel isolated or excluded themselves }\end{array}$ & $\begin{array}{l}\text { 1.If there are difficulties in my work, } \\
\text { I was assisted by supervisor } \\
\text { 2.I feel a mutual support among } \\
\text { fellow employees } \\
\text { 3.If I get in trouble at work, finish my } \\
\text { own because a colleague or boss } \\
\text { does not want to help }\end{array}$ \\
\hline
\end{tabular}

TABLE III: HEXACO PERSONALITY SCALE

\begin{tabular}{|c|c|c|}
\hline Dimension & Subdimension & Items \\
\hline \multirow[t]{4}{*}{$\begin{array}{l}\text { Honesty - } \\
\text { Humility }\end{array}$} & Sincerity & $\begin{array}{l}\text { I will not pretend to like } \\
\text { someone just to get the benefit } \\
\text { of that person }\end{array}$ \\
\hline & Fairness & $\begin{array}{l}\text { I will not receive any bribe, } \\
\text { even its very large }\end{array}$ \\
\hline & Greed- Avoidance & $\begin{array}{l}\text { I feel enough with what i have } \\
\text { today }\end{array}$ \\
\hline & Modesty & $\begin{array}{l}\text { I think that } \mathrm{i} \text { am entitled to be } \\
\text { more valued than people in } \\
\text { general }\end{array}$ \\
\hline \multirow[t]{4}{*}{ Emotionality } & Fearfulness & I'm affraid to do corruption \\
\hline & Anxiety & $\begin{array}{l}\text { I'm not easy to worry about the } \\
\text { little things }\end{array}$ \\
\hline & Dependence & $\begin{array}{l}\text { When being experienced a } \\
\text { painful events, i need someone } \\
\text { to make me feel comfortable }\end{array}$ \\
\hline & Sentimentality & $\begin{array}{l}\text { I'm often feeling sad when see } \\
\text { other people sad }\end{array}$ \\
\hline \multirow[t]{4}{*}{ Extraversion } & Social Self Esteem & $\begin{array}{l}\text { Curently i feel satisfied with my } \\
\text { self }\end{array}$ \\
\hline & Social Boldness & $\begin{array}{l}\text { In social situation, i usually start } \\
\text { the conversation in the first time }\end{array}$ \\
\hline & Sociability & $\begin{array}{l}\text { I do like work in a group instead } \\
\text { of working by myself }\end{array}$ \\
\hline & Liveliness & $\begin{array}{l}\text { First thing that } i \text { always do in the } \\
\text { new place is finding a new } \\
\text { friend }\end{array}$ \\
\hline \multirow[t]{4}{*}{ Agreeableness } & Forgiveness & $\begin{array}{l}\text { I rarely feel grudge to someone } \\
\text { who has hurt me }\end{array}$ \\
\hline & Gentleness & $\begin{array}{l}\text { If i do something wrong,then i } \\
\text { will not hesitate to say sorry }\end{array}$ \\
\hline & Flexibility & $\begin{array}{l}\text { I am flexible with my } \\
\text { opinion,eventhough other } \\
\text { people disagree with me }\end{array}$ \\
\hline & Patience & I'm a patience person \\
\hline \multirow[t]{4}{*}{$\begin{array}{l}\text { Conscientious } \\
\text { ness }\end{array}$} & Organitization & $\begin{array}{l}\text { To anticipate certain situation, } \mathrm{i} \\
\text { always made a plan }\end{array}$ \\
\hline & Diligence & $\begin{array}{l}\text { I usually pushing myself when } \mathrm{i} \\
\text { want to achieve something }\end{array}$ \\
\hline & Perfectionism & $\begin{array}{l}\text { I'll always try to make } \\
\text { something perfect }\end{array}$ \\
\hline & Prudence & $\begin{array}{l}\text { When i want to make a decision, } \\
\text { my logical always influence me } \\
\text { more instead of my feelings }\end{array}$ \\
\hline \multirow[t]{4}{*}{$\begin{array}{l}\text { Opennes to } \\
\text { Experience }\end{array}$} & Aesthetic & $\begin{array}{l}\text { If i have a chance, } i \text { want to } \\
\text { study art }\end{array}$ \\
\hline & $\begin{array}{l}\text { Appreciation-Inqui } \\
\text { stiveness }\end{array}$ & $\begin{array}{l}\text { I'm interesting to learn about } \\
\text { history and politics }\end{array}$ \\
\hline & Creativity & $\begin{array}{l}\text { People usually stated that i have } \\
\text { broader imagination }\end{array}$ \\
\hline & Unconventionality & $\begin{array}{l}\text { According to me, learning } \\
\text { philosophy is something } \\
\text { interesting }\end{array}$ \\
\hline
\end{tabular}

TABLE IV: MORAL INTEGRITY SCALE

\begin{tabular}{|l|l|}
\hline Dimensions & \multicolumn{1}{|c|}{ Items } \\
\hline Moral & $\begin{array}{l}\text { Discernment } \\
\text { I feel good about myself knowing corruption is } \\
\text { essential to who I am as a person }\end{array}$ \\
\cline { 2 - 2 } & $\begin{array}{l}\text { I have had tried to understand why avoiding corruption } \\
\text { Behavior is right for me to do }\end{array}$ \\
\cline { 2 - 2 } $\begin{array}{l}\text { Doing corruption is something I know I should not do } \\
\text { Behavior }\end{array}$ & $\begin{array}{l}\text { I feel it is my responsibility to be honest in most aspects } \\
\text { of my life }\end{array}$ \\
\cline { 2 - 2 } & I consistently try to be honest and avoid corruption \\
\cline { 2 - 2 } & $\begin{array}{l}\text { I have the conscious objective of being honest in my } \\
\text { life }\end{array}$ \\
\hline Public & $\begin{array}{l}\text { I feel comfortable explaining to others why I believe } \\
\text { that anti corruption is important to me }\end{array}$ \\
\cline { 2 - 2 } & $\begin{array}{l}\text { I continue to live according to my value even when } \\
\text { others don't like it }\end{array}$ \\
\cline { 2 - 2 } & $\begin{array}{l}\text { I have thought about how other people should be honest } \\
\text { in their lives as well. }\end{array}$ \\
\hline
\end{tabular}


TABLE V: ANTI - CORRUPTION INTENTION SCALE

\begin{tabular}{|l|l|}
\hline \multicolumn{1}{|c|}{ Dimension } & Item \\
\hline Anti-bribe & $\begin{array}{l}\text { In the line of duty I never expect and will not } \\
\text { accept any giving from others }\end{array}$ \\
\hline Anti-gratification & $\begin{array}{l}\text { If someone give me a gift after I finished my } \\
\text { job, I will not accept it }\end{array}$ \\
\hline Anti-fraud & $\begin{array}{l}\text { Using office stuff for my personal benefit is } \\
\text { something that will decrease my self dignity }\end{array}$ \\
\hline Anti-mark up & $\begin{array}{l}\text { I never thinking to exaggerate price in office } \\
\text { procurement }\end{array}$ \\
\hline Anti-black mail & $\begin{array}{l}\text { I usually giving a gift to others to avoid } \\
\text { difficulty }\end{array}$ \\
\hline Anti-nepotism & $\begin{array}{l}\text { Objectivity and profesionality are very } \\
\text { important to be implemented in work }\end{array}$ \\
\hline
\end{tabular}

\section{Result}

Our first stage to analyze the data was tested the validity of all measuring scales in this study with CFA (Confirmatory Factor Analysis) and continued with the help of Lisrell Software.

Furthermore, the authors see that there is connection between independent variable (religious orientation, moral integrity, personality, organizational climate) and dependent variable (anti-corruption intention). The results can be seen in figure below.

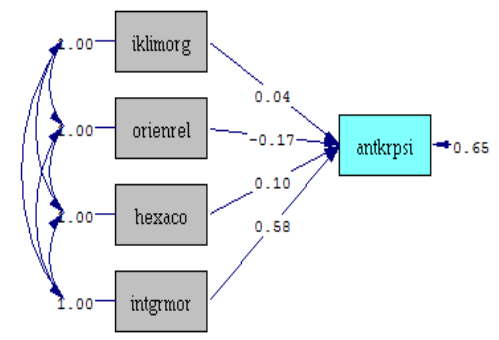

Chi-Square $=0.00, d f=0, P-v a l u e=1.00000$, RMSEA $=0.000$

Fig. 2. Result from data analysis.

The resume from the chart above can be seen in the table below:

TABLE VI: DESCRIPTIVE RESULT FROM DATA ANALYSIS

\begin{tabular}{|c|l|l|l|l|l|}
\hline $\begin{array}{c}\text { Dependent } \\
\text { Variable }\end{array}$ & $\begin{array}{c}\text { Religious } \\
\text { Orientati } \\
\text { on }\end{array}$ & Personality & $\begin{array}{c}\text { Organiz } \\
\text { ational } \\
\text { Climate }\end{array}$ & $\begin{array}{c}\text { Moral } \\
\text { Integrity }\end{array}$ & \\
\hline \multirow{4}{*}{$\begin{array}{c}\text { Anti-corrup } \\
\text { tion } \\
\text { behavior }\end{array}$} & -0.17 & 0.10 & 0.04 & 0.58 & Coeff \\
\cline { 2 - 6 } & 0.08 & 0.10 & 0.07 & 0.09 & $\begin{array}{c}\text { Std. } \\
\text { Error }\end{array}$ \\
\cline { 2 - 6 } & 2.23 & 1.00 & 0.58 & 6.79 & tvalue \\
\hline
\end{tabular}

It can be concluded that the independent variables that affect the behavior of anti-corruption is religious orientation variables with coefficient $-0.17(t>1.96)$, and moral integrity variables with regression coefficient of $0.58(t>1.96)$, while the rest did not significantly affect the anti-corruption intentions.

TABLE VII: STATISTICAL DESCRIPTIVE RESULTS

\begin{tabular}{|c|c|c|c|c|}
\hline & $\begin{array}{c}\text { Organiza } \\
\text { tional } \\
\text { Climate }\end{array}$ & $\begin{array}{c}\text { Religious } \\
\text { Orientation }\end{array}$ & $\begin{array}{c}\text { Moral } \\
\text { Integrity }\end{array}$ & $\begin{array}{c}\text { Anti-Corruptions } \\
\text { Intention }\end{array}$ \\
\hline High & 110 & 107 & 96 & 101 \\
\hline Low & 92 & 95 & 106 & 101 \\
\hline Total & 202 & 202 & 202 & 202 \\
\hline
\end{tabular}

The author uses the median value of each variable to ultimately determine the level of someone on these variables. Based on the above table, high categories on organizational climate variable number of 110 respondents, while the lower number of 92 categories of respondents. Then in the religious orientation, total respondents in the category of high, numbered 107, while the lower category amounted to 95 people. Then the variable moral integrity has 96 respondents in the high category, while in the lower category number 106. Finally, the anti-corruption behavior variables both high and low categories at the same numbered 101 respondents.

\section{Recommendation}

Based on our research, we proposed some recommendation that can be used:

1) The necessity of education that instills moral values from an early age, which is given by the family and educational institutions in order to form a national identity that has moral integrity.

2) For the organizations, aside of establish clear rules and procedures, it is important also to provide training session in order to build good character implement religious values and also moral integrity.

\section{REFERENCES}

[1] F. Rosarians. (2013). ICW: Indonesia Corruption Not Passed So State. [Online].

Available: http://222.tempo.co/read/news/2013/12/09/063535765/ICW-Indonesi a-Tak-Lulus-Jadi-Negara-Antikorupsi

[2] Ironi Menteri Agama. (2008). [Online]. Available: http://pendidikanagama.com/237.html

[3] D. Ancok, Industrial Psychology, BPP UGM, 1992

[4] G. W. Allport and M. J. Ross, "Personal religious orientation and prejudice," Journal of Psychology and Personality, vol. 5, pp. 432-443, 1967.

[5] M. C. Ashton, K. Lee, and L. R. Goldberg, "A hierarchical analysis of 1,710 English personality-descriptives adjectives" Journal of Personality and Psychology, vol. 87, pp. 707-721, 2004.

[6] Ministry of Religious Affairs, "With the supervision of religious approach," Inspectorate General of the Ministry of Religious Affairs, Jakarta, 2004

[7] What is moral integrity? Anti-corruption programs. (2012). [Online]. Available: http://www.ethic-intelligence.com

[8] Wirawan, Culture and Organizational Climate Research Theory and Applications, Jakarta: Salemba Four, Corruption-Prone-Sector in MORA, 2011.

[9] M. Fishbein and I. Ajzen, Belief, Attitude, Intention and Behavior: an Introduction to Theory and Research, Sydney: Addison Wesley Publishing Company, 1975.

[10] Ajzen, The Theory of Planned Behavior. Organizational Behavior and Human Decision Process, University of Massachusetts at Amherst Academic Press, Inc, pp. 50, 179-121, 1991.

[11] M. C. Ashton and K. Lee, "Empirical, theoretical, and practical advantages of the hexacomodels of personality structure," Personality and Social Psychology Review, vol. 11, pp. 150-166, 2007.

[12] A. Bandura, Social Foundation of Thought and Action, New Jersey: Prentice Hall, Inc, 1986

[13] L. M. Olson. (2002). Moral Integrity. [Online]. Available: http://www.charis.wlc.edu/publications/

[14] J. K. Preacher, Rucker, and D. Hayes, "Addressing hyphoteses moderated mediation: theory, methods, and prescriptions," Multivariate Behavioral Research, vol. 42, no. 1, pp. 185-227, 2007

[15] D. B. P. Riyanti and Dahesihsari, "Study work behavior and organizational behavior Indonesian context of global challenges to local excellence," Faculty of Psychology, Atma Jaya Catholic University, Jakarta, 2008.

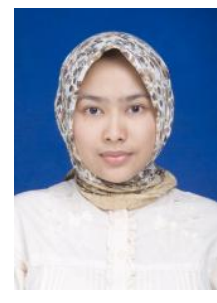

Zulfa Indira Wahyuni was a psychologist, who was born in Sukabumi, on May 9, 1981. She graduated from University of Indonesia in 2007 and got post graduated degree in child clinical psychology. She has been working as a lecturer, child clinical psychologist and child division of Child \& Gender Study Center in State Islamic University of Jakarta. She is interested in doing research in child psychology, social psychology, and psychology of religion. 
Yufi Adriani was a psychologist, who was born in Jakarta, on September 18, 1982. She graduated from University of Indonesia in 2006 and got post graduate degree in clinical psychology. She is working as a lecturer, psychologist, and the head of Psychology Laboratory in State Islamic Unversity of Jakarta. She is interested in doing research in social psychology, positive psychology and clinical psychology.

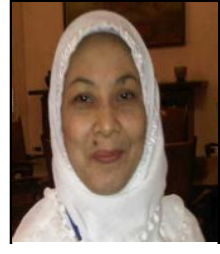

Zahrotun Nihayah was born in Tuban, on July 24 1962. She graduated from University of Indonesia in 2006 and got post graduate degree in developmental psychology. She is currently working as a lecturer and the head of Psychological Service Center in State Islamic University of Jakarta. She is interested in doing research in social, family and developmental psychology. 